\title{
Perception of people with visual disability on guidance and counselingservice in self-concept development
}

\author{
Elvina Oktavia ${ }^{1}$, A. Muri Yusuf ${ }^{2}$, Yanuar Kiram ${ }^{3}$ \\ ${ }^{123}$ Universitas Negeri Padang, Padang, Indonesia, (oktaviavina141@gmail.com)
}

\begin{abstract}
The various experiences of people with visual disability about guidance and counseling in Bina Netra Social House "Tuah Sakato" Padang caused kinds of perceptions. The research were to describe the perception of low vision and total blindness and also the distinct perception about guidance counseling in self concept development. The type of the research was comparative descriptive. By using purposivesampling method, about 30 of them were chosen to be the sample. The instruments used was Guidance and Counseling Perception Scale (GCPS) which was read by the researcher. Data of the research was analyzed by using Mann-Whitney U Test. The result of the research shows there is no significant differenceperception between people with low vision and total blindness. It means both of them have good perception about guidance and counseling in self concept development.
\end{abstract}

Keywords: perceptions, people with visual disabilit, guidance and counseling

\section{Introduction}

Education aims to develop the potential of learners. Every individual is entitled to education through formal and nonformal education in order to achieve a better life. This applies to individuals studying in special education pursuant to Law No. 20 of 2003 on National Education System. These provisions provide a strong foundation for learners, especially blind people to get equal opportunities in education and teaching in special education.

Somantri (2007) argues that the blind is an individual whose two senses sight sense do not function as a receiving channel of information in daily activities as well as watchers (can see). The limitations experienced by the individual have a negative impact on their physical, psychological, social, educational and economic functions (Sing-Fai, Chan, Hoi, \& Lam, 2003). This happens because they tend to get pressure in their environment that prevents them from mixing in the community. Although blind people are able to utilize other functioning senses, the label of disability becomes one of the emergences of a negative self-assessment, so they feel that others treat themselves differently. The tendency to judge negatively affects the self-concept it has.

Essentially, self-concept is called the way a person sees himself. Brooks (in Rakhmat, 2012) defines the concept of self as the physical, social, and psychological perception of ourselves that we have derived from experiences and our interaction which others. This statement has the meaning that the 
concept of self is the views and feelings about the self that includes aspects of psychological, social, and physical. According to Lawrence \& Vimala (2013) self-concept is an important element in the growth and developmental process for individual human beings. This statement explains that selfconcept is an important element in individual development. Individuals with low self-concept will feel unsure of their abilities, tend to withdraw from the environment and end up isolated in it (Cambra \& Silvestre, 2003; Tice \& Wallace, 2003). In line with previous opinions, the results of research by Pijl \& Frostad (2010) show that people with disabilities are more susceptible to isolation and rejection from the environment negatively impact on self-concept and motivation in conducting activities.

Well-developed self-concept is characterized by the ability to understand, assess and be able to develop themselves positively. Therefore, people with visual impairment need services that support the development of potential with a positive gain on him. According to Kustawan (2013) services that can be provided include Guidance and Counseling Service, which emphasizes the development of daily living skills and is very important in preparing for the future of the visually impaired. Prayitno \& Amti (2015) asserts that all individuals are entitled to equal opportunity in obtaining Guidance and Counseling services. Likewise, blind people who have the right to obtaining Guidance and Counseling service in order to be able to develop his self-concept. Ideally, Guidance and Counseling services are based on Guidance and Counseling principles as the basis for the implementation of the service. According to Bernard \& Fullmer, (1969) and (1979); Crow \& Crow, (1960); Miller \& Freuhling, (1978) (in Prayitno \&Amti, 2015) the principles of Guidance and Counseling are, among others, the principles of service objectives, individual issues, service programs and service delivery. However, the principle concerning the person with the visual impairment is the service target and the individual problem.

Guidance and Counseling services have a good influence on the development of self-concept, but it is possible if the services provided are not fully understood positively by the blind. This is influenced by several factors, one of which is perception. Perception is referred to as giving meaning to an object based on experience. According to Rachmat (2012), perceptions pertain to an object, event, or relationship gained from experience by summing up information and interpreting the message. The perception of each individual will be different if the experience experienced and felt different from each other. Similarly, the perception of people with visual impairment about Guidance and Counseling services in the development of self-concept, because the perceived is not visual but perceived from the way of thinking.

Based on observations and interviews with Guidance and Counseling teachers at BinaNetra Social Institution (PSBN) "TuahSakato" Padang City on February 20, 2017 obtained information that people with visual impairment need Guidance and Counseling service to develop the concept itself in a positive direction, because it is still found by blind people comparing himself with his friend. This is in line with the results of research Datta\&Talukar (2015) that the low self-concept of blind people caused by often comparing themselves with peers. Furthermore, the form of behavior that is suspected from the result of blind people's perception related to Guidance and Counseling service that is blind people does not enter at service hours for various reasons. Still, there is a blind person who thinks Guidance and Counseling service is not important because they feel able to solve the problem that happened. Thus, some people with visual impairment have not been able to positively interpret the Guidance and Counseling service provided. The purpose of this study is to describe: (1) the perception of people with visual impairment or low vision about Guidance and Counseling service in self concept development, (2) blind person with blindness totally about Guidance and Counseling service in self concept development, and (3) is there difference of perception of low vision visual impairment with total blindness of Guidance and Counseling services in the development of self-concept. 


\section{Method}

The type of this research is comparative descriptive. The population of this research is blind people following Guidance and Counseling service for 45 years and 30 samples. Sampling using purposive sampling technique. The instrument in the form of Likert scale is Perception Scale of Counseling Guidance Service (PSCGS) which have reliability equal to 0,937 by way read by the researcher. The data were analyzed with Mann-Whitney U Test formula through SPSS version 20.00 to know the difference of blind person perception about Guidance and Counseling service in selfconcept development.

\section{Results and Discussion}

\section{Low Vision Blind People's Perception of Guidance and Counseling Service in Self-Conception Development}

Data of people with visual impairment low vision regarding perceptions about Guidance and Counseling service that amounted to 16 respondents. The results showed that as many as $100 \%$ of 16 low vision respondents overall have perceptions that are in the high category $(\mathrm{T})$, meaning that people with visual impairment low vision have a good perception of Guidance and Counseling services in the development of self-concept. In general, people with visual impairment low vision have perceptions that are in the high category, and specifically found some score items that are in the category of being. That is, some people with visual impairment low vision have a "good enough" perception of some content in Guidance and Counseling service.

Based on the previous explanation, can be analyzed some statements that get the lowest item score related to personal and social aspects. Statements relating to the personal aspect of the inherent developmental barriers. While related to the social aspect is the ability to foster social relationships in the orphanage. The low perception of related statements on personal and social aspects is thought to be a factor of satisfaction. According to the phenomenon that occurs in the orphanage, people with visual impairment low vision have a better skill compared with blind people with total blindness. It can be indicated that the low vision blind has not been able to face its social environment with appropriate strategies and needs more attention in its development. Accordingly, Kirk \&Galagher (Suharmini, 2000) argues that low vision blind persons have a lower self-concept than the total blind because the total blindness has more appropriate strategies for dealing with their social environment. Therefore, the Guidance and Counseling Teachers need to evaluate the services provided, so that the root of the problem faced by the visually impaired low vision related to personal and social aspects, so that the services provided Guidance and Counseling can be implemented optimally.

According to Prayitno\&Amti (2015), to optimize counseling and guidance services according to individual needs, it is necessary to recognize and understand the uniqueness of each individual with various strengths, weaknesses, and problems. Likewise, with individual development, the Guidance and Counseling Teachers must understand the various aspects of individual development as well as to see the direction of individual development in the future as well as its relation to innate and environmental factors (Sulistyarini\&Jauhar, 2014).

\section{Blind Persons Concerning Total Blind on Guidance and Counseling Service in Self-Concept Development}

The results showed that as many as $100 \%$ of the 14 respondents overall have a good perception of BK services in the development of self-concept is categorized high (T). That is, blind blind people have a good perception of Guidance and Counseling service because it is able to help the 
development of his concept. Despite having a good overall perception, but still found the results obtained score item statement that is in the category of being. That is, some blindly blind people have a "pretty good" perception of the content in Guidance and Counseling service. The lowest score was obtained on statements regarding difficulty in following Guidance and Counseling services. Based on the statement, blind people with blindness experienced difficulties in joining Guidance and Counseling service, where they tend to rely on people with visual impairment in low vision in following an activity. Sumekar (2009) has the same opinion that the characteristic of blind totally blind is to have excessive dependence.

Based on the highest score, it is obtained on the statement item regarding the provision of solutions to the social development that is hampered. Overall, the blind totally blindly perceives well the Guidance and Counseling service with regard to providing solutions for him/her. Given that blind people with total blindness are more dependent than those with low vision blindness, the BK service provided is interpreted as a pleasant service. This happens because they have a good experience and respond with a good attitude too. In line with the opinion of Prayitno\&Amti (2015) attitudes and behavior of individuals is also influenced by aspects of personality and conditions themselves and the condition of the environment.

Based on the perception of blind persons with total blindness related to the provision of solutions, it can be concluded that Guidance and Counseling teacheralways tries to provide direction and assistance in its development. It's just that to note is in the provision of assistance, Guidance and Counseling teachersdoes not look at the light angle of an obstacle or problem. If theGuidance and Counseling teacher views the problem as something mild, then it is unlikely that the Guidance and Counseling teachersis serious about providing assistance. Conversely, if the Guidance and Counseling teacher acts excessively or feel unable to feel it will be too difficult to deal with so that it can harm the blind people (Prayitno \& Amti, 2015).

\section{Blind Persons with Blindness Total Concerned about Guidance and Counseling Service in Developing Self Concept}

The results showed that there was no difference in perception of low vision visual impairment with total blindness about Guidance and Counseling service in self-concept development. This is indicated by the value of $Z$ perception obtained at -0.400 with the significance of 0.689 . Basic decision making is if sig $>0,05$, then $\mathrm{H} 0$ is accepted, but if sig $<0,05$, then H0 is rejected (Santoso, 2012). Based on the significance of the $\mathrm{Z}$ value, the null hypothesis is accepted. It can be said that the perception of blind and low vision blind people about Guidance and Counseling service in the development of the self-concept is not different (same/homogeneous). So that it can be concluded, blind people with low vision and total blindness have a good perception about Guidance and Counseling service in the development of the self-concept.

Theabsence of differences in perception of the visually impaired low vision with total blindness is likely to be related to two things, namely (1) self-adjustment, and (2) motivation. The factors that affect the ability of individuals in adjusting one of them is the environment (Pasmawati, 2012). The state of a good environment, full of acceptance and understanding, is an environment that will help the process of self-adjustment of the visually impaired. Bina Netra Social Home Environment not only provides education for people with visual impairment but also creates the interests, beliefs, attitudes, and values that become the basis of good adaptation. Likewise with the Guidance and Counseling service in the orphanage that helps the development potential of the visually impaired. Thus, people with visual impairment or low vision and total blindness get support from the orphanage to develop their potential, thushaving a good perception of Guidance and Counselingservices in the development of self-concept. 
According to Robbins (in Nirwana, 2003) perception is closely related to behavior. The behavior that individuals show in an environment is strongly influenced by their perceptions of the environment. Individuals who are encouraged to analyze an object have a better perception than those who do not get encouragement (Elbaum, 2002). The more positive the perception of the blind person about an object, the more likely it will be more positive also the behavior of the object. Conversely, the more negative the perception of an object, the more likely it will be the more negative one's behavior towards the object. The second factor related to the absence of different perception of the blind person about BK service in the development of the self concept is the motivation of the blind person.

Research conducted Khairina (2009) concluded that the perception and motivation have a significant and positive influence. Uno (2009) suggests that motivation is an impulse arising from the stimulation from within and outside so that someone is eager to make a change of behavior / certain activities better than the previous state. Motivation also has a distinctive role in terms of growing passion, feeling happy and the emergence of spirit (Sadirman, 2012).

Every individual has the power within himself to act/act in accordance with his needs. The willingness of the blind to volunteer to follow the Guidance and Counseling service in the development of self-concept becomes the marking factor that the blind person is motivated to do so. Volunteering is seen from the physical and psychological aspects of people with visual impairment because actions are motivated mentally also influenced by cognitive functions such as related to perceptual factors (Schunk, 2008). Individuals who have high motivation will usually take advantage of something that is considered beneficial in achieving its goals. People with visual impairments who have good perceptions tend to use Guidance and Counseling services to develop self-concept in order to achieve effective daily life (KES).

Based on the findings of this study can be taken a general conclusion that the perception of people with visual impairment low vision and total blindness have a good perception. Guidance and Counseling teachersneeds to maintain the services provided by Guidance and Counseling in the development of self-concept related to physical, social and psychological aspects so that people with visual impairment have better perception and self-concept so that their life is meaningful after leaving Bina Netra Social Institution.

\section{Conclusion}

People with visual impairment low vision have a good perception and are in the high category. That is, the service provided by Guidance and Counseling is able to help the development of the selfvisual concept of visually impaired low vision, although they have difficulty in facing the social environment with appropriate strategy and require more attention to the obstacles of its development.

People with visual blindness totally have a good perception and are in the high category. That is, the services provided by Guidance and Counseling are able to help the development ofblind selfconcept totally, although they have more dependence when compared with the totally blind person.

There was no significant difference between the perception of people with visual impairment with low vision and total blindness about Guidance and Counseling services in the development of selfconcept. The results obtained are inseparable from various factors that affect the perception of people with visual impairment low vision and total blindness. 


\section{Acknowledgments}

Based on the process of completion of the results of this study, researchers get much help and guidance from various parties. As an expression of gratitude, the researcher conveyed to the honorable:

Prof. Dr. A. Muri Yusuf,M.Pd., as Advisor and Prof. Dr. Phil. YanuarKiram., as the second counselor who always take the time to provide guidance, direction, science, and motivation is meaningful to researchers for the perfection of writing the results of this study.

Prof. Dr. Mudjiran, M.S., Kons., Prof. Dr. Herman Nirwana, M.Pd., Kons., And Dr. Syahniar, M.Pd., Kons., as a contributor as well as assisting researchers in weighing (judge) research instrument that has provided direction, suggestions, and input in completing thesis writing.

\section{References}

Cambra, C., \& Silvestre, N.(2003). Students with Special Educational Needs in the Inclusive Classroom; Social Integration and Self-Concept.European Journal of Special Needs Education. 18, 197-208.

Datta, P., \& Talukar, J. (2015). The Impact of Vision Impairment on Students Self Concept. International Journal of Inclusive Education. 2(4), 1360-3116.

Elbaum, B. (2002). The Self-Concept of Students with Learning Disabilities: A Meta-Analysis of Comparisons Across Different Placements. Journal of Learning Disabilities Research \& Practice, 17(4), 216-226.

Khairina. (2009). “Analisis Faktor Pengaruh Motivasi, Persepsi, Pembelajaran, dan Kepribadian Terhadap Keputusan Pembelian Laptop di Kalangan Mahasiswa Fakultas Teknik Universitas Syiah Kuala Banda Aceh". Tesis tidak diterbitkan. Medan: Pascasarjana Universitas Sumatera Utara.

Kustawan, D. (2013). Bimbingan dan Konseling Bagi Anak Berkebutuhan Khusus. Jakarta: Luxima Metro Media.

Lawrence, A.S.A., \& Vimala, A. (2013). "Self Concept and Achievement Motivation of High School Students". International Journal, 1(1), 2320-9305.

Nirwana, H. (2003). "Hubungan Tingkat Aspirasi dan Persepsi Tentang Belajar dengan Hasil Belajar Matematika Siswa Sekolah Menengah Umum yang Berlatar Belakang Budaya Minangkabau dan Batak".Disertasi tidak diterbitkan. Malang: Universitas Negeri Malang.

Pasmawati, H. (2012). Penyesuaian Diri Mahasiswa dalam Belajar dan Prestasi Belajar serta Implikasinya terhadap Bimbingan dan Konseling. Tesis tidak diterbitkan. Padang: Prodi S2 BK FIP UNP.

Pijl, S. J., \& Frostad, P. (2010). Peer Acceptance and Self Concept of Students with Disabilities in Regular Education.European Journal of Special Needs Education, 25(1), 93-105.

Prayitno \& Amti, E. (2015). Dasar-Dasar Bimbingan dan Konseling. Jakarta: Rineka Cipta.

Rakhmat, J. (2012). Psikologi Komunikasi. Bandung: Remaja Rosdakarya.

Sadirman. (2012). Interaksi dan Motivasi Belajar Mengajar. Jakarta: Rajawali.

Santoso, S. (2012). Panduan Lengkap SPSS Versi 20. Jakarta: Elex Media Komputindo.

Schunk, D. H. (2008). Motivation in Education: Theory, Research, and Applications. New Jersey: Pearson Prentice Hall. 
Sing-Fai, T., Chan, M.H., Hoi, W.L., \& Lam, L.H. (2003). Comparing the Self Concept of Hong Kong Chinese Adults with Visible and Not Visible Physical Disability. The Journal of Psychology. 137(4), 363-372.

Somantri, S. (2007). Psikologi Anak Luar Biasa. Bandung: Refika Aditama.

Suharmini, T. (2000). Kecemasan Sosial Remaja Tunanetra ditinjau dari Konsep Diri dan Persepsinya terhadap Remaja Awas. Jurnal Iptek dan Humaniora. 5(2).

Sulistyarini \& Jauhar, M. (2014). Dasar-dasar Konseling (Panduan Lengkap Memahami Prinsip-Prinsip Pelaksanaan Konseling). Jakarta: Prestasi Pustakaraya.

Sumekar, G. (2009). Anak Berkebutuhan Khusus. Padang: UNP Press.

Tice, D.M., \& Wallace, H.M. (2003). The Reflected Self: Creating yourself as (you think) others see you. In handbook of Self and Identity, ed. M.R. Leary and J.P. Tangney, 99-105. New York: Guildford Press.

Undang-undang Nomor 20 tahun 2003 tentang Sistem Pendidikan Nasional.

Uno, H.B. (2007). Teori Motivasi dan Pengukurannya. Jakarta: Bumi Aksara. 